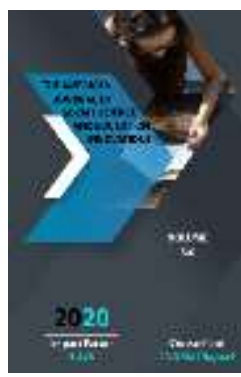

\title{
Description Of Global Problems In Uzbek Drama Period Of Independence (On the example of E.Azam's drama "Lonely boat")
}

\author{
Vazirakhon Askarovna Akhmedova \\ Researcher, Tashkent State Pedagogical University named after Nizami, Tashkent, Uzbekistan
}

Journal Website:

http://usajournalshub.c

om/index,php/tajssei

Copyright: Original

content from this work

may be used under the

terms of the creative

commons attributes

4.0 licence.

\section{ABSTRACT}

This article is deals with the tragedy of the Aral Sea, which today has become a global problem not only in Uzbekistan but also around the world, and its negative impact on humanity. The article analyzes the play "The Lonely Boat" by E.Azam, given how deeply the playwright's knowledge of national life, poetic skills, style, reveals the inner world of the heroes (national image, thoughts, psycho-psychological drama).

\section{KEYWORDS}

Globalization, image, art, legend, remark, drama, tragedy, conflict, culmination, comment, replica, monologue, dialogue.

\section{INTRODUCTION}

It is well known that the visual subject of the arts of drama and cinema is based on action. Cinematography, which is an integral part of screen art, was formed on the basis of technical means. It brought together creative staff such as writer-dramatist, director, actor, cameraman, painter, composer into a single team and popularized it as a type of artistic creation. Indeed, its combined the aesthetic aspects of arts such as literature and theater, fine arts and music. Effective use of expressive tools such as large-scale plan, parallel editing, extended panorama, especially cooperation with the TV screen, has increased its capabilities. The use of different forms of polyphony enriched the film in terms of genre 
and style. Therefore, its ideological and artistic sphere of influence covered such areas of socio-political, cultural and enlightenment education as the influence on human thought, the formation of worldview, the enhancement of aesthetic taste. [1.87-89-p]

Screenwriting, on the other hand, is a separate type of fiction designed to be shown on the screen, a syncretic phenomenon that arises from the fusion of film and drama. Consequently, the literary and ideologicalartistic basis of the film is the screenplay. The playwright must take into account the possibilities of cinema during the filming, adapt the work to it. In particular, the form of an independent work should be of both literary and cinematographic nature, reflecting not only the content but also the structure of the film to be created. So, it is important to combine such factors as the scale of the prose, the sharpness of the drama, the lyrical subtlety of poetry, the brightness of the image, the musical fluency, the sharpness of the dialogues.

\section{MAIN PART}

E.Azam's poems "Where is Paradise?", "Shajara", "Dream of the cleaning lady", "The owner of the apartment", "The dream of a lonely boat or a madman" were staged in the republican theaters. His plays such as "Chantrimore" (1990), "Pedestrian" (1996), "Dilxiroj" (2001), "Man" (2004), "Zabarjad" (2007), "By the Water" (2008), "Where is Paradise?" (2008), "The Debtor" (2010), "Parizod" (2012) have been filmed. Some of the above-mentioned works have been successfully shown in the cinemas of the republic, while others have been rightly recognized even in the international arena. In particular, the film "Dilxiroj" was shown on German and French television screens, and a copy was shown at the Fukuoka Film Museum in Japan. The film "Man" won the nomination "Best Screenplay" at the International Film Festival "Kinoshock". He also won the Grand Prix of the International Film Festival in Vesoul, France. The film "Zabarjad" was awarded a special diploma at the "Moscow Premiere" and the CIS conferences, and won the nomination "Best Actress" at the film festival in the country. The film "By the Water" won the "Silver Knight" award at the Golden Knight International Film Forum in Moscow. This achievement allowed the film to participate in the Asian Film Festival in New York (USA). This time he won the nomination "Best Actor". "Parizod" won the Grand Prix at the Kinoshock International Film Festival.

Of course, such achievements have led to the globalization of E. Azam. The playwright said: “... as if these conferences were a film lesson for the fireplace, in the course of his creative travels around the world, [4, 5-p], E. Azam learned the subtleties of the industry and made many friends. In fact, the best achievements of world cinematography are presented in the form of genre or interregional competitions of cinematographic works. Award-winning and prize-winning places will be determined, and the next directions of development of the industry will be determined. Different folk artists exchange creative ideas with each other. Arts and cultures are getting closer. Therefore, the lessons of the film festival added to what Azam learned from Uzbek filmmakers such as Temurmalik Yunusov and Yusuf Rozikov.

In general, it is safe to say that the films of E. Azam also play a role in the further development of Uzbek cinema. Commenting on his creative process, the author writes: “... I give them a bit of a cinematic tone, call it a lazy film story, but from the very beginning I write 
for the book: if a film is made, it is made, [4,6p], otherwise it is read. This allows us to say that in the works of E. Azam created a plastic image of the object, that is, in them the creative personality is embedded in the object, it is possible to read and accept these artistic texts, which are the basis of theater and cinema.

For example, Erkin Azam's film "Lonely Boat" is a mosaic of forty-one short chapters, which, according to its structure, consists of an introduction, main part and conclusion. When we talk about the artistic text of this work, we mean the creative side of filmmaking, not production. Although the script for the theater and cinema is based on a global problem, such as the recent Aral Sea tragedy, it does not reflect the real being itself. Nor does it claim explicit documentation.

Therefore, "Lonely Boat" is not a purely scientific and popular work, despite the fact that it is a historical script that expresses the problem of nature and society. This is an obstacle to the analysis and research of the writer's point of view, his deep knowledge of national life, his poetic skills, style, how he was able to reveal the inner world of the heroes (national image, thoughts, psychopsychological drama), cannot be to assess the artistic value of the script.

Trying to avoid the usual form of content and looking for new ways to engage the audience, E.Azam observed the socio-educational problems in this play with a poetic romantic look. In order to bring a modern interpretation to the historical theme, he sometimes resorted to the methods of artistic expression typical of folklore and classical literature, and sometimes to socio-philosophical interpretations.
In particular, the fact that the genre of the work is defined as "cinematographic" indicates that the experiences of the genre of "narrative" of folklore have been creatively mastered. The introduction [4.171-172 p.] to the work begins with a narrative narrative, similar to folk tales. Although the play does not involve folk heroes or real historical figures, its main idea is based on historical reality. The root causes of the island tragedy are being sought. Ideal norms of morality, otherness, faith are promoted. The narration of the pir and the consequent murid, which is included as a prelude, is incorporated into the content of the film as in the classical literary tradition, and serves to reveal the spirit of Aral Baba, a hopeful from the great abode of the Truth, as a man of deep faith and soul. [4.189-p.] The image of the unknown horseman supporting old man is also interpreted as a missing slave. The transition of such a situation to the parentchild dialogue clearly shows the conflict of views in the film:

Kalimbet: - Yes, yes! What about Hajj? Father, are you thinking? Who will go on Hajj without you ?! If you have not harmed anyone, if you have not betrayed, if you do not look at anyone's property and life ...

Aral bobo: - (melted). To be honest, I've seen it a couple of times, son. The heart did not dare: whoever you are, it is as if you dream of a pilgrimage. But let me tell you a secret: sometimes I feel like I've been there! Even with the intention ...

Kalimbet: - (comes to life). Now you are really going, father! All your documents are ready! Aral bobo: - (with open mouth). Yes, you could pass me by before ... 
Kalimbet: - Whether I pass or not, now the problem is solved! I spoke instead of one by one! ...

Aral bobo: - What? Instead of someone ?! (Both hands in front, limping, as if fleeing from trouble). I'm not going! Did you think of that yourself, Kalimbet! This is a great sin. [4.195]

It is clear from the above dialogue in the literary-artistic text that Aral Bobo differs from his brother-in-law Kalimbet and his people not only in the recognition of the characters, but also in the purity of intentions, words and deeds.

In this sense, the lofty aspirations of the Aral bobo to return the sea to its original state are nourished, in part, by the fact that E. Azam seeks a religious answer to the problem of nature conservation, appeals to the verses of the Qur'an and Islamic teachings. Indeed, in verse 30 of Surat al-Anbiya, it is said, "... and We have created from water every living thing," and in verse 45 of Surat an-Nur, it is said, "Allah created all living things from water."

Indeed, both the origin and the composition of the living universe are water, and it is impossible to imagine life on earth without water. Shaykh Muhammad Sadiq Muhammad Yusuf, who discussed the same issue, commented on the blessing of water and the rulings not to waste it wrote in the books of jurisprudence of our scholars. [4.195]

So, at the time of writing the film, E. Azam was acquainted with the Islamic instructions that water is a great blessing of Allah, not to waste it and pollute it, and tried to absorb the narrations of the hadith scholars as much as possible. The fact that the Aral ancestor strives to stay away from the tyrannical people, adorns his life with beautiful human qualities, and sincerely believes that there is a lot of wisdom in the objectivity of intentions, is a sign of faith and idolatry.

The author's comments on the details of the stage movement and the speech process during the event - the remarks also serve to bring to life the essence of the reality that is happening in the imagination. After all, through the comments we find a convincing answer to the question of how E.Azam's eyes "saw" those events and how he "heard" the words of the characters, and we partially follow him. In particular, due to his son's offer to go on a pilgrimage and his attention to his father, Aral Bobo, like any father, "melts" at first, but "revives" when he expresses his inner sorrows and sincere intentions. Qalimbet "opens his mouth" because he decided his fate without asking for a word of mouth. When a Muslim man learns that even a hair of Qalimbet's hair has not changed, that acquaintances have interfered in sending the believers on a holy prayer journey, it is explained as above. Changes in situational requirements as described above are reflected in the tone, tone, tempo, pauses, body position, facial expressions, hand gestures, gestures, and abrupt actions of the Aral ancestor. Undoubtedly, by giving such details, E.Azam, on the one hand, enhances the stage, on the other hand, manages to show the character of the protagonist in the process of harmony of internal and external movements. As we have seen, the film depicts the life of a man ("Aral Bobo") who has left his childhood ("Orolbola"), adolescence ("Oroltoy"), youth ("Orolboy") and has now entered the old stage of his life. Aral Bobo, a fisherman whose real name has been forgotten and who has lost his beloved sea, takes his beloved boat, which is his constant companion, on the roof of his house and pays homage to it. In addition to the figurative interpretation in the details of his 
making new boats with his disciples and installing them on the roofs of good people, the crazy dreams of the hero's nature also come to the fore. In fact, this is exactly what was meant when the theatrical version of the play was called "The Dream of a Lonely Boat or a Madman."

\section{CONCLUSION}

It is clear that Aral Bobo, although seemingly insane, is in fact a man of deep devotion and wings. That is why he explains the drying up of the Aral Sea by saying, "Satan's slaves stirred up the wrath of God." Accustomed to his son's "invitations" and going to the city through the streets, he considers it a betrayal of the sacred place where his ancestors and his wife lived, as well as his lifelong beloved donkey and boat. [4.179-180-6.] He never tires of installing the boats he has built on the roofs of people of faith, honesty and purity. Because the boats on the roof are the material symbols of the grandfather's pleas for rain from the sky and water from the sea. [4.183-6.]

Of course, the actions of Aral Baba seem "crazy" to those who seek economic benefits from everything, such as his son Kalimbet, daughter Gulzira and his friend Rohat Sobirovna, Otagan (father of his favorite student Genjamurod). Gulzira, who is not ashamed to do business in the shadow of a woman and lives as a lover under the auspices of her relatives, who promoted her to parliament, sees herself as modern and her father's "tricks" as commercial. So he goes as far as to put his father's buzrukvori in the insane asylum. It is worth noting that in places where the old man is placed in this place and mysteriously escaped with the help of good people, there are also fairy-tale narratives and detective interpretations. A magical sound is heard behind the bot-bot dignity. This voice reminds Aral grandfather of the otameros fishing profession, his bright memories of his past, especially his lover Oykumush, and all his deeds. Unfortunately, the playwright cannot elevate the "voice" detail to the level of the protagonist's heartbeat.

It is clear that time has left its mark on man and mother nature. However, all the changes in the main space took place in connection with the life of the Aral ancestor, more precisely, his destiny, which is closely connected with the place where he lived. The terrible event that took place at the same time as a human life the retreat of the sea in the distance and the emergence of a sandstorm desert in its place lives in the memory of the old man, with all its socio-spiritual splendor.

In the concluding part of the work, the whitecap Aral grandfather and four young boys (Jumaboy, Tilovbergan, Genjamurod, Amet), who respect the cow, suffer from thirst. Of course, E.Azam sought to add symbolic meaning to this thirst. This is reflected in the fact that the minds of the heroes are not left with cherished memories of the sea, nostalgia for it, the desire to reach the ocean and a sense of constant aspiration. Importantly, heroes with a clear purpose do not stop in one breath. Pure intentions give wings to their hopes.

So, in the film story "The Lonely Boat" by E. Azam, the impact of the Aral Sea tragedy on humanity is artistically described, and the main idea of the play defines its symbolic content, moral, philosophical and didactic essence.

\section{REFERENCES}

1. Abul-Kasymova X. Birth of Uzbek cinema. T. 1965; Teshabaev Dj. Puti and poiski. - T. 1972; Teshabaev Dj. Uzbek cinema: traditions, innovation. - T. 1979; AbulKasymova X., Teshabaev Dj., 
Mirzamuxamedova M. Movies of Uzbekistan. - T. 1985

2. Anikst A. The story of learning about drama. - M .: Nauka, 1988.

3. Aristotle. Poetics. Morality is a grave. A new generation. - Tashkent 2004.

4. Azam E. A solitary boat. Kinorivoyat. // Erkin A'zam. A solitary boat. Movie Stories. Sharq NMAK General Editorial Office, - T. 2017. - Б. 195.

5. Volkenstein V.M. Dramaturgy. - M .: Writer. 1990.

6. Didro D. Sobranie sochineniy. -T.5.- $M$.: Nauka, 1983.

7. Yoqubov I. "The magic of artistic and aesthetic words." -T ; "New Century Generation" - 2011

8. Yuldashev. Q. Burning word. -T .: Yangi asr avlodi, 2006.

9. Karimov $H$. Literature of the independence period. - T .: New edition, 2010

10. Lessing G.E. "Hamburg Drama". - M .: Xudojestvennaya literatura, 1953.

11. Monteske Sh. Izbrannye proizvedeniya. M .: Literature, 1955.

12. Normatov U. Sophisticated gurungs. $-\mathrm{T}$.: Muharrir, 2010.

13. Soliev A. Interpretation of life and man. - T .: Turon zamin ziyo, 2015.

14. Sultan I. "Literary Theory". -T .; Teacher, 2005, $270 \mathrm{p}$.

15. Sheikh Muhammad Sadiq Muhammad Yusuf. Iman. Sharq NMAK General Editorial Office, - T.2006. - B.84

16. Quronov D., Mamajonov Z., Sheralieva M. Dictionary of Literary Studies. - $T$.: Akademnashr, 2010

17. Kuronov D. Fundamentals of literary theory. - T .: Akademnashr, 2018. 